\title{
Assessment of Mercury Intake from Fish Meals Based on Intervention Research in the Polish Subpopulation
}

\author{
Renata Kuras $^{1}$ - Beata Janasik ${ }^{1}$ Magdalena Stanislawska ${ }^{1}$ - Lucyna Kozlowska ${ }^{2}$. \\ Wojciech Wasowicz ${ }^{1}$
}

Received: 19 September 2016 / Accepted: 10 January 2017 /Published online: 27 January 2017

(C) The Author(s) 2017. This article is published with open access at Springerlink.com

\begin{abstract}
The paper's objective was to estimate weekly $\mathrm{Hg}$ intake from fish meals based on intervention research. Total $\mathrm{Hg}(\mathrm{THg})$ concentrations in blood and hair samples collected from men $(n=67)$ from an intervention study as well as muscular tissues of fresh and after heat-treating fish were determined using the thermal decomposition amalgamation atomic absorption spectrometry method (TDA-AAS) using direct mercury analyzer (DMA-80). The mean of the estimated weekly intake (EWI) was estimated at $0.62 \mu \mathrm{g} / \mathrm{kg} \mathrm{bw} / \mathrm{week}$ in the range $0.36-0.96 \mu \mathrm{g} / \mathrm{kg}$ body weight (bw) /week through the consumption of 4 edible marine fish species every day (for 10 days) by the participants from the intervention research in Lodz, Poland. The Hg intake in the volunteers in our intervention study accounted for $38.6 \%$ of the provisional tolerable weekly intake (PTWI) $(1.6 \mu \mathrm{g} / \mathrm{kg}$ bw, weekly) value. The average $\mathrm{Hg}$ concentration in the analyzed fish ranged from $0.018 \pm 0.006 \mathrm{mg} / \mathrm{kg}$ wet weight (Gadus chalcogrammus) to $0.105 \pm 0.015 \mathrm{mg} / \mathrm{kg}$ wet weight (Macruronus magellanicus). The results for the average consumers were within PTWI of methylmercury (MeHg). Moreover, the average concentration of $\mathrm{Hg}$ in the selected fish after heat treatment did not exceed the maximum permitted concentrations for $\mathrm{MeHg}$ (MPCs $=0.5 \mathrm{mg} / \mathrm{kg}$ wet weight) in food set by the European Commission Regulation (EC/1881/2006). Hence, the risk of adverse effects of $\mathrm{MeHg}$ for the participants is substantially low.
\end{abstract}

Renata Kuras

Renata.Kuras@imp.lodz.pl

1 Department of Biological and Environmental Monitoring, Nofer Institute of Occupational Medicine, 8 Teresy St, 91-348 Lodz, Poland

2 Department of Dietetics, Faculty of Human Nutrition and Consumer Sciences, Warsaw University of Life Sciences, Warsaw, Poland
Keywords Mercury $\cdot$ Environmental exposure $\cdot$ Fish consumption $\cdot$ PTWI $\cdot$ TDA-AAS

\section{Introduction}

Food contamination is an issue that still raises attention. Harmful side effects for human health resulting from the intake of food contaminated with chemical substances have been the most frequently observed ones [1]. One of neurotoxicants that have received most attention with this respect is methylmercury $(\mathrm{MeHg})$. The risk assessment for $\mathrm{MeHg}$ is based primarily on the data obtained in the past, i.e., on epidemiological studies (large-scale), which related to fish consumption among pregnant/breastfeeding mothers/ children [2].

Humans are exposed to organic forms of mercury through fish and seafood consumption, in particular top predatory fish such as swordfish, marlin, king mackerel, tile fish, shark, and tuna. Fish may accumulate $\mathrm{MeHg}$ directly from water (first $\mathrm{Hg}$ in water is converted by sulfatereducing bacteria into an organic form) or through consuming other organisms (biomagnification of the food chain). Total $\mathrm{Hg}$ concentration in fish is often used as a measure of $\mathrm{MeHg}$ exposure, assuming that almost $100 \% \mathrm{Hg}$ concluded in fish and seafood occurs in $\mathrm{MeHg}$ [3]. In the gastrointestinal tract, $\mathrm{MeHg}$ is absorbed to an extent of about $95 \%$. Its lipophilic properties facilitate a smooth transition between the blood-brain barrier (BBB) as well as placental barrier, which impairs metabolism of the nervous system. Mercury compounds, both organic and inorganic, are extremely toxic due to the high affinity with thiol groups of enzymes and proteins. Ingestion of fish contaminated with $\mathrm{MeHg}$ can lead to adverse health outcomes (ataxia, paresthesia, dysarthria, hearing defects, visual disturbances) [4]. 
Health risks regarding consumption of $\mathrm{Hg}$-contaminated fish are subject to regulation introduced by many countries and government agencies. The European Union Commission Regulation [5] sets maximum levels (MLs) only for total mercury content (THg) for fish and seafood from $0.5-1.0 \mathrm{mg} / \mathrm{kg}$ wet weight. In view of the above, the Joint Food and Agriculture Organization of the United Nations and World Health Organization FAO/WHO Expert Committee on Food Additives (JECFA) has established provisional tolerable weekly intake (PTWI) for MeHg as the amount of contaminant (e.g., $\mathrm{MeHg}$ ), which is not cleared rapidly from the body and that can be ingested over a lifetime without appreciable risk. The PTWI value is calculated for a week due to the bioaccumulation of the contaminants (e.g., toxic elements) in humans.

The PTWI for MeHg of $1.6 \mu \mathrm{g} / \mathrm{kg}$ bw/week corresponds to $0.112 \mathrm{mg} /$ week for a person weighing $70 \mathrm{~kg}$. The PTWI for $\mathrm{THg}$ is $4 \mu \mathrm{g} / \mathrm{kg}$ bw/week [6, 7]. The (US) National Research Council (NRC) established an intake limit of $0.7 \mu \mathrm{g} / \mathrm{kg} \mathrm{bw} /$ week, the 2.3-fold lower limit than that of JECFA [4].

The estimated $\mathrm{Hg}$ intakes are different between the European countries and depend on the amount and the type of fish consumed. In Poland, the PTWI value based on the European Food Safety Authority (ESFA) [5, 8] is in line with the JECFA and concerns $\mathrm{Hg}$ and $\mathrm{MeHg}$ in food.

Assessment of exposure to $\mathrm{MeHg}$ can be carried out on the basis of measurements of $\mathrm{Hg}$ in food (fish and fishery product) or based on the results of biological monitoring of $\mathrm{Hg}$ concentrations in blood (Hg-B) and hair $(\mathrm{Hg}-\mathrm{H})$. $\mathrm{Hg}-\mathrm{B}$, in particular $\mathrm{Hg}-\mathrm{H}$, are routinely used as biomarkers to assess $\mathrm{MeHg}$ exposure $[9,10]$. Until recently, to determine mercury content in biological materials, various methods of digestion-utilizing chemical reagents (strong bases or acids) or in combination with microwave mineralization were used $[11,12]$. The latest method is measurement by means of cold vapor atomic absorption spectrometry (CVAAS) [13] or by inductively coupled plasma mass spectrophotometer (ICP-MS) after microwave-assisted acid digestion [14]. However, the simplest and most effective method of $\mathrm{Hg}$ determination, where sample preparation or other wet chemistry is not required before the analysis, is the direct mercury analyzer DMA-80 [15, $16]$.

In order to estimate the dietary intake of chemical substances, chemical analysis and appropriate estimation methods are used. We can choose one of the three variants of contamination levels: the most probable case (estimation of single or short-period intake, for instance over a week), the average case (for a long period), and the extremely high case - mostly 90th percentile of the distribution of concentrations or an average of $10 \%$ of the results of the highest value. The last is connected with consuming food from one source, mostly from heavily industrialized areas. In this paper, the authors chose the first option. Estimation of dietary exposure to $\mathrm{MeHg}$ in fish was based on the assumption that almost $90 \%$ of the total $\mathrm{Hg}$ that is present in fish meat, fish products, fish offal, and seafood exists in the form of $\mathrm{MeHg}$ [8]. In order to assess the risk of adverse health effects among individuals who consume more fish meals than average, it is necessary to estimate the intake of heavy metals contaminating this food.

The main objective of this study was to estimate whether the PTWI value of MeHg for men in Poland is safe. The projected intake values of $\mathrm{Hg}$ through human consumption were calculated (microgram per kilogram body weight (bw) weekly) and compared with the PTWI value as stipulated by the JECFA/ESFA. Moreover, this paper examined variations in $\mathrm{Hg}$ concentrations in blood and hair as biomarkers of $\mathrm{MeHg}$ intake correlated with fish consumption as well as $\mathrm{Hg}$ levels in fish commonly eaten by the Polish subpopulation.

\section{Materials and Method}

\section{Study Design and Participants}

An intervention study, which was undertaken between June and August 2015, involved 71 healthy men from the Nofer Institute of Occupational Medicine (NIOM) in Lodz, Poland. The participants were recruited via the information posted in NIOM and were informed about the aim of the study and of the examinations to be performed and then signed informed consent forms. In order to obtain the basic data needed for the research, personal survey and the food frequency questionnaire (FFQ) were conducted. The survey included questions about age, body mass index (BMI), current smoking status, diet (including intake of fish oil or supplements containing shark cartilage), alcohol, and medical history. Four individuals were rejected from the study due to fish oil and omega-3 fatty acid supplementations. The study men were aged 21-64 years with a mean age of 41 years. Their BMI was $26.9 \pm 4.3 \mathrm{~kg} / \mathrm{m}^{2}$ in the range of $17.8-40.2 \mathrm{~kg} / \mathrm{m}^{2}$. The $21 \%$ of the subjects were current smokers. The $34 \%$ had from one to five dental amalgam fillings. The FFQ showed that the diet of the study individuals was similar. The FFQ provided us with details concerning fish consumption among the individuals. According to the FFQ, 9\% of the volunteers never (or almost never) ate fat fish (e.g., salmon, sardines, herring, mackerel, big carp, eel), $50 \%$ ate such fish once a month or more seldom, and $40 \%$ several times a month. The lean fish (e.g., pollock, cod, perch, hake, carp, small tuna, pangasius, trout) consumption presents as follows: never or almost never-4\%, once a month or less $-52 \%$, and several times a month $-41 \%$. None of the study subjects ate supplements containing shark cartilage or fish oil. Seventy-six percent of the individuals never or almost never ate game meat, $20 \%$ once a month, or more seldom. 
The types of fish were selected based on the market analysis of fish consumption in Poland (Institute of Agricultural and Food Economics National Research Institute (IAFENRI), data from the year 2014). According to the data of the IAFE-NRI, in Poland, in 2013 and 2014, the biggest increase in fish consumption per one resident in the total consumption of fish concerned salmon and cod, while the Polish consumers most frequently ate pollock (up to $25 \%$ of the chosen fish). Of eight initially selected fish, four marine fish species of the family Gadiformes with higher concentration of $\mathrm{Hg}$ were selected. Patagonian (Macruronus magellanicus other name Patagonian grenadier), pollock (Gadus chalcogrammus), cod (Gadus morhua), and coalfish (Pollachius virens) came in a form of frozen filet samples (without skin) from the Polish market. The fish species were caught in the zone of the Pacific Ocean in fishing area FAO 87 (M. magellanicus) and FAO 61 (G. chalcogrammus) and in the area north-east Atlantic FAO 27 (G. morhua, P. virens).

The intervention research consisted in daily fish consumption (frying fish dishes) for 10 days ( 2 weeks with the exception of Saturdays and Sundays). The volunteers ate on three consecutive days M. magellanicus (the first week) and $G$. morhua (the second week) and on two consecutive days $G$. chalcogrammus (the first week) and $P$. virens (the second week). During the whole study, all the participants consumed approximately $1.6 \mathrm{~kg}$ of fried fish, which was equivalent of about $0.16 \pm 0.006 \mathrm{~kg}$ of fried fish daily. Study participants ate fish in a canteen of the NIOM. Each portion of fish (without spices and butter) was weighted before and after frying. The fish was fried (common frying temperatures $170-190^{\circ} \mathrm{C}$ ) in rapeseed oil from 5 to $10 \mathrm{~min}$. With the purpose of monitoring $\mathrm{Hg}$ concentrations in blood and hair, the samples were collected within certain intervals. On the first day (named "test I") of fish consumption, blood and hair samples were collected and the FFQ questionnaire was carried out. Then, after 1 week (named "test II") and at the end of the second week of fish consumption (named "test III"), blood samples were collected. Finally, 1 month after the study (named "test IV"), blood and hair samples were collected once again. The study was approved by the Ethics Committee of the Nofer Institute of Occupational Medicine in Lodz, Poland.

\section{Specimen Collection}

Blood was collected into a Venosafe tube (free from trace and heavy metals) containing Lithium Heparin as anticoagulant and stored at $-20{ }^{\circ} \mathrm{C}$ until analysis.

For determination of $\mathrm{Hg}$ in hair, about $10 \mathrm{mg}$ of hair samples with 1-cm length was collected. The hair was cut with scissors from the occipital area of the head at the hair root and placed in a polyethylene bag and stored at room temperature until the analysis. Due to the fact that all the participants were men, the hair samples were only rinsed with acetone and deionized water (18-MW). The hair washing procedure is recommended by the International Atomic Energy Agency (IAEA) [17]. We applied no additional washing method assuming that none of the volunteers used hair sprays, mousses, gels, and oils.

\section{Direct Mercury Analyzer DMA-80}

Total mercury concentrations of muscular tissues of fish (fresh and after heat treating - frying) as well as hair and blood samples collected from the men were determined on sample boats using the thermal decomposition amalgamation atomic absorption spectrometry method (TDA-AAS) (direct wercury analyzer DMA- 80 by Milestone, Spectro-Lab, Poland). The working principle of the instrument is based on the thermal decomposition, catalytic conversion, amalgamation, and atomic absorption spectrophotometry. The absorption intensity was measured at $253.7 \mathrm{~nm}$. The decomposition products are carried by continuous flow of pure oxygen through a catalyst bed, where interferences are eliminated.

The analytical balance Sartorius Quintix model (Q224 $1 \mathrm{CEU}$ ) with internal calibration was used to weigh the hair and fish samples using units of milligrams.

The linear calibration curve in the range $0.5-10.0 \mathrm{ng}$ was plotted as absolute mass of $\mathrm{Hg}$ (nanogram) versus absorption peak area. The correlation coefficient $r=0.9998$ was achieved. $D_{\mathrm{L}}$ and $Q_{\mathrm{L}}$ were counted as 3 times $\left(\mathrm{D}_{\mathrm{L}} 3 \mathrm{~s}\right.$ for blank $)$ and 6 times $\left(\mathrm{Q}_{\mathrm{L}} 6 \mathrm{~s}_{\text {for blank }}\right)$ of standard deviation for blank and were $0.0025 \mathrm{ng}$ and $0.0051 \mathrm{ng}$, respectively.

Accuracy of the method was checked by the regular use of the certified reference material: DOLT-5 (fish liver, National Research Council of Canada, NRC - CNRC) and standard reference material: NIST 2976 (SRM-Mussel Tissue, Trace Elements and Methylmercury, Freeze-dried). To check determination of mercury in hair, we used human hair powder reference material: NCS DC 74337 (Certified Reference Material, China National Analysis Center for Iron and Steel, China).

Seronorm trace element whole blood reference material (RM) as well as blood samples from the international program of the German External Quality Control (G-EQUAS) was used for the method development and validation. All the results of the analyzed (certified) reference materials had satisfactory recoveries from 95\% (DOLT-5) to $107 \%$ (NCS DC 73347a).

To prepare standard solutions containing mercury we used an inorganic mercury standard stock solution $(1000 \mu \mathrm{g} \mathrm{Hg} / \mathrm{ml}$ in 2\% HNO3; JT Baker), hydrochloric acid $(36.5-38 \% \mathrm{HCl}$; JT Baker), and deionized water (resistivity of $18 \mathrm{M} \Omega \mathrm{cm}$ ) in the Milli-Q Integral 3 system (Millipore, Bedford, MA, USA). The blood was collected into Venosafe tube containing Lithium Heparin (VF-054SHL). 


\section{Statistical Analysis}

Statistical analysis was conducted using Statistica 8.0 sofware (StatSoft Inc., Poland). Significance was established at the level of $p \leq 0.05$. We tested deviation from the HardyWeinberg equilibrium using the chi-square test. The ShapiroWilk test was used to determine normality of distribution [18, 19].

\section{Results}

\section{Mercury in Fish}

The average concentration of $\mathrm{Hg}$ in muscle tissues of fish is presented in Table 1. The average Hg concentration in the analyzed fish ranged from $0.018 \pm 0.006 \mathrm{mg} / \mathrm{kg}$ wet weight and $0.023 \pm 0.006 \mathrm{mg} / \mathrm{kg}$ wet weight ( $G$. chalcogrammus) to $0.105 \pm 0.015 \mathrm{mg} / \mathrm{kg}$ wet weight and $0.109 \pm 0.015 \mathrm{mg} / \mathrm{kg}$ wet weight (M. magellanicus), respectively, in raw and fried fish and decreased (both in a raw and fried state) as follows: $M$. magellanicus $>G$. morhua $>P$. virens $>G$. chalcogrammus. Fried fish contained slightly higher amount of $\mathrm{Hg}$ than raw fish with a mean of $0.058 \pm 0.033 \mathrm{mg} / \mathrm{kg}$ (median $=0.053$ and 95th percentile $=0.115)$ and $0.054 \pm 0.034 \mathrm{mg} / \mathrm{kg}$ (median 0.044 and 95 th percentile 0.119 ), respectively. The differences between $\mathrm{Hg}$ level in raw and fried fish species were from $0.4 \%$ for $M$. magellanicus, $0.5 \%$ for $G$. chalcogrammus, $1.1 \%$ for G. morhua to $1.4 \%$ for $P$. virens.

Moreover, average concentration of $\mathrm{Hg}$ in selected fish after heat treatment did not exceed the maximum permitted concentrations (MPCs $=0.5 \mathrm{mg} / \mathrm{kg}$ ) in food set by the commission regulation [5].

\section{Blood-Hair Relationship}

The blood samples were taken before dosing and during the test, then they were analyzed for mercury concentrations. Mean concentration of $\mathrm{Hg}$ in the whole blood ( $\mathrm{Hg}-\mathrm{B}$ microgram per liter) of the volunteers on the first day of fish consumption was found to be $0.62 \pm 0.41 \mu \mathrm{g} / \mathrm{l}$ (NS); after 1 week, it was $0.90 \pm 0.46 \mu \mathrm{g} / 1(p<0.001)$; in the end of the study, $1.28 \pm 0.49 \mu \mathrm{g} / \mathrm{l}(p<0.001)$, and 1 month after the end of the study (test IV), $0.78 \pm 0.60 \mu \mathrm{g} / \mathrm{l}(p<0.001)$. The average increase in the Hg-B concentration was from 0.62 to $1.28 \mu \mathrm{g} / \mathrm{l}$. Distribution of the whole blood total $\mathrm{Hg}$ measured in 67 men during the intervention is presented in Fig. 1 (the first day and after 10 days of fish consumption).

Mean concentration of $\mathrm{Hg}$ in hair $(\mathrm{Hg}-\mathrm{H}$ microgram per gram) of the volunteers on the first day of fish consumption was found to be $0.24 \pm 0.16 \mu \mathrm{g} / \mathrm{g}$ (NS), and 1 month after the end of the study (test IV), it was $0.29 \pm 0.15 \mu \mathrm{g} / \mathrm{g}(p<0.05)$. Distribution of total $\mathrm{Hg}$ in the hair of the study individuals

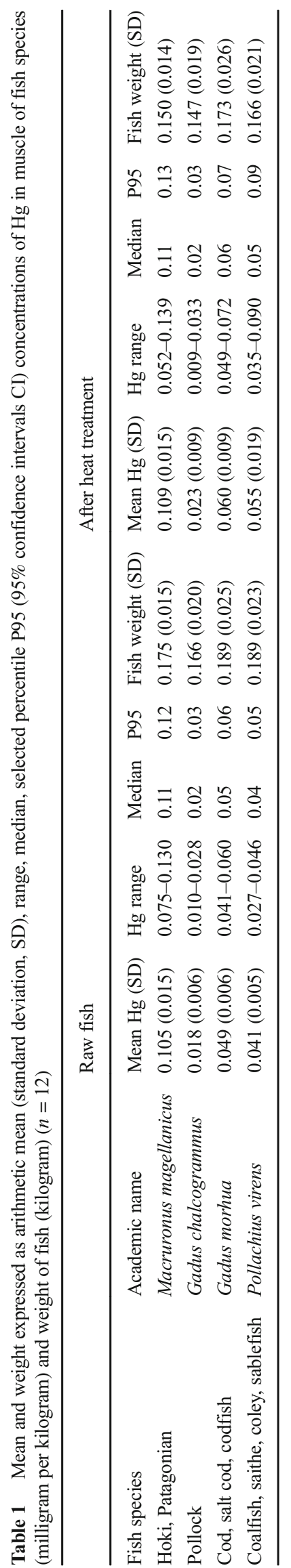


Fig. 1 The distribution of $\mathrm{THg}$ concentration in whole blood samples measured in 67 men during intervention

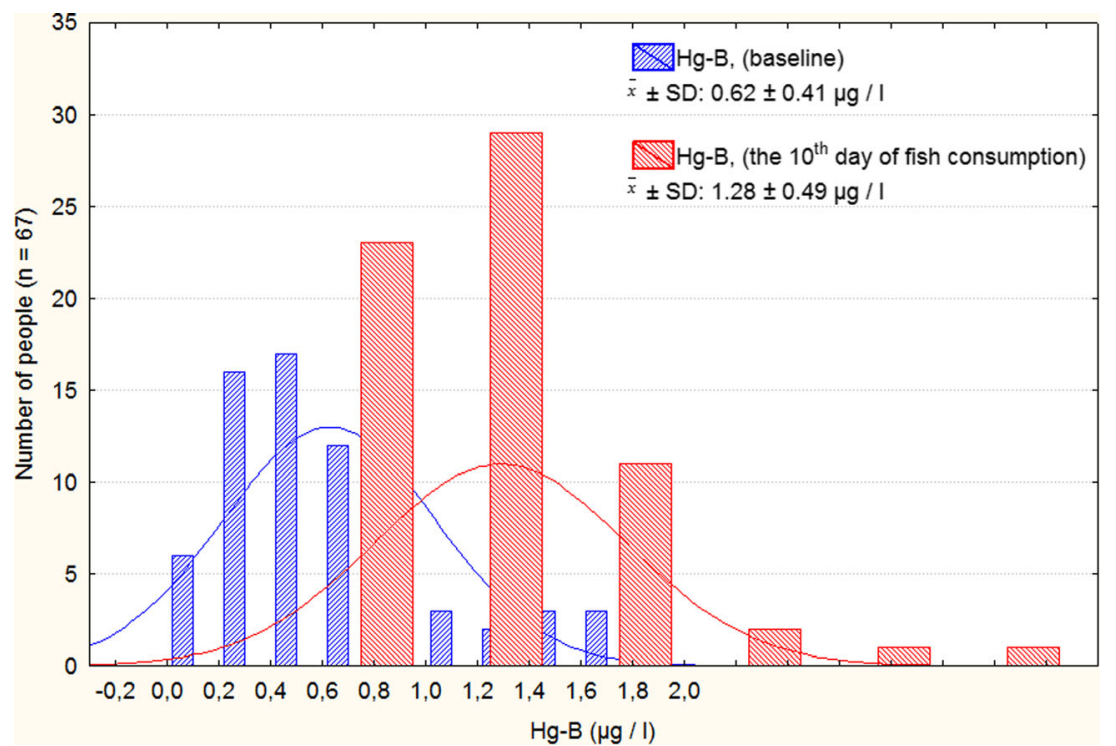

during the intervention (the first day and 1 month after the end of the study) is presented in Fig. 2. Hg concentration in the hair depended strictly on the amount of consumed fish and the level of their pollution with mercury.

The average $\mathrm{Hg}$ hair to $\mathrm{Hg}$ blood ratio was 0.23 (median $=0.22 ; 95$ th $=0.35$; range $=0.069-0.442$ ). Figure 3 presents concentration of mercury in the hair 1 month after the end of the study in relation to blood (Hg-B microgram per liter) collected at the end of the study (on the 10th day of fish consumption).

\section{Assessment of Mercury Intake from Fish}

Taking into account that $\mathrm{Hg}$ content was expressed as microgram per kilogarm of fried fish samples and numbers of consumed fish portions, the calculated intake during 10 days of fish consumption amounted to $105 \mu \mathrm{g}$. The estimated daily intake of $\mathrm{Hg}$ in the dietary intervention study was $10.5 \mu \mathrm{g}$ for $\mathrm{Hg}$. The $\mathrm{MeHg}$ (microgram per kilogram) intake per kilogram of body weight per week was calculated by multiplying the amount of fish ingested per week (kilogram per week) and $\mathrm{Hg}$ concentrations in the ingested fish (microgram per kilogram) divided by body weight (kilogram). The estimated weekly intake (EWI) of $\mathrm{Hg}$ in our research, which equaled $0.62 \mu \mathrm{g} / \mathrm{kg}$ $\mathrm{bw} /$ week (median $=0.62$; the range $=0.36-0.96$ ), was within the PTWI value.

In the case of a person weighing $70 \mathrm{~kg}$ and consuming a meal consisting of $150 \mathrm{~g}$ of $M$. magellanicus and $173 \mathrm{~g}$ of $G$. morhua three times a week, $\mathrm{Hg}$ intake was higher for $M$.
Fig. 2 The distribution of $\mathrm{THg}$ concentration in hair samples measured in 67 men during intervention

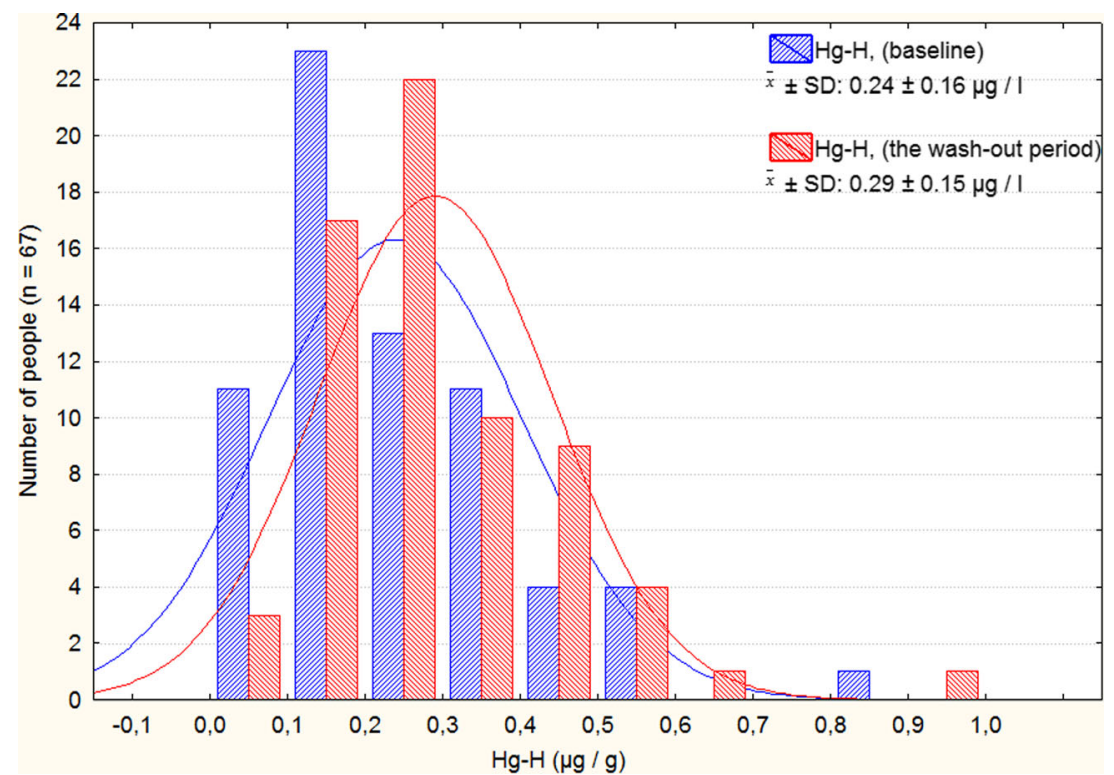


Fig. 3 The relationship between THg-H and THg-B in 67 men evaluated by linear regression

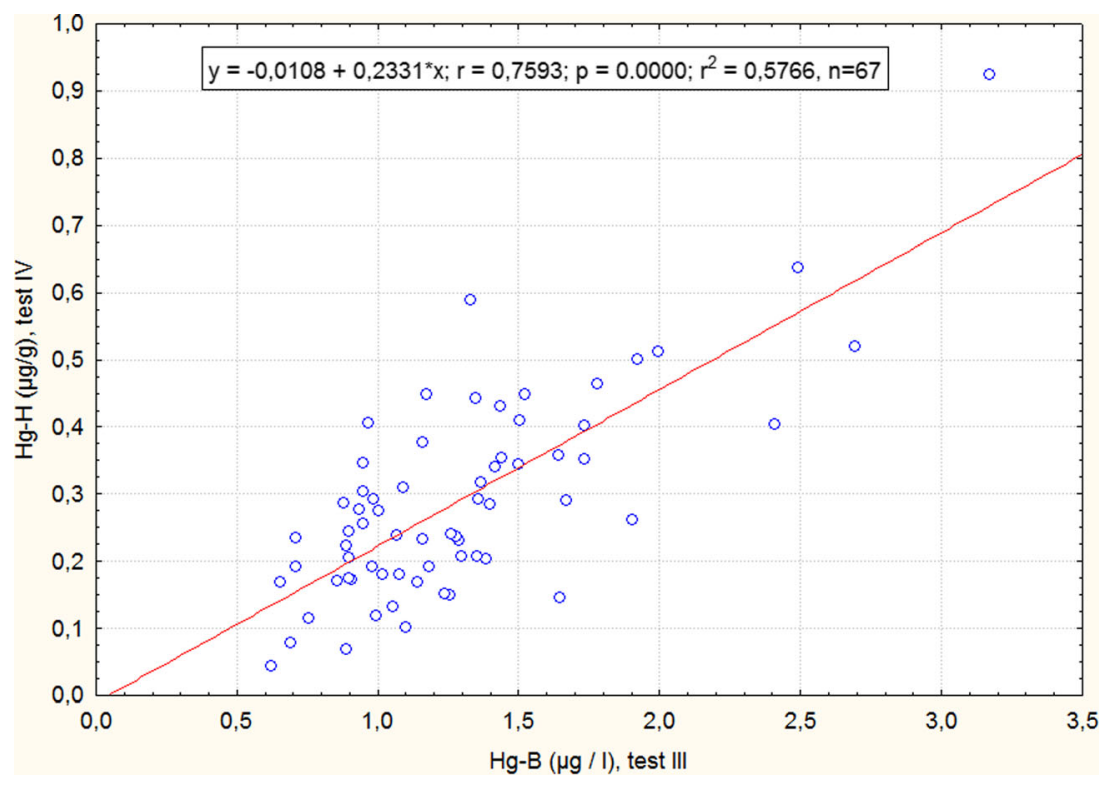

magellanicus than for G. morhua ( 0.70 vs. $0.45 \mu \mathrm{g} / \mathrm{kg}$ bw). Correspondingly, in the case of a meal consisting of $147 \mathrm{~g}$ of $G$. chalcogrammus and $166 \mathrm{~g}$ of $P$. virens two times a week, $\mathrm{Hg}$ intake was higher for $P$. virens than for $G$. chalcogrammus $(0.26$ vs. $0.09 \mu \mathrm{g} / \mathrm{kg} \mathrm{bw})$. In our research project, the estimated weekly intake of $\mathrm{Hg}$ amounted to $0.62 \mu \mathrm{g} / \mathrm{kg} \mathrm{bw} /$ week (38.6\% of the PTWI), which corresponds to $0.04 \mathrm{mg} / \mathrm{week}$ for a person weighing $70 \mathrm{~kg}$. The $\mathrm{Hg}$ intake was evaluated based on consumption of $800 \mathrm{~g} / \mathrm{week}$. The average mercury concentration in raw fish was $0.054 \pm 0.034 \mathrm{mg} / \mathrm{kg}$ and the 90 percentile level of $0.12 \mathrm{mg} / \mathrm{kg}$; thus none of the determined samples of fish exceeded the limits established in the European Union for this toxic metal $(0.5 \mathrm{mg} / \mathrm{kg}$ for $\mathrm{Hg})$. Fried fish contained slightly higher amount of mercury than raw fish with a mean of $\mathrm{Hg} 0.058 \pm 0.033 \mathrm{mg} / \mathrm{kg}$.

\section{Hg in Relation to Age, Smoking Status, and Amalgam Fillings}

No significant differences in $\mathrm{Hg}$ concentration was found between the smokers and nonsmokers at the beginning of the study. $\mathrm{Hg}-\mathrm{B}$ were found to be $0.48 \pm 0.38 \mu \mathrm{g} / \mathrm{l}$ and $0.66 \pm 0.42 \mu \mathrm{g} / \mathrm{l}$ (NS), respectively. Also, no significant changes in $\mathrm{Hg}-\mathrm{B}$ concentration between the people with and without dental amalgam fillings was observed, i.e., $(0.57 \pm 0.35 \mu \mathrm{g} / \mathrm{l}$ and $0.63 \pm 0.42 \mu \mathrm{g} / \mathrm{l}$ (NS), respectively. There were no statistically significant differences between the smokers and nonsmokers and between the people with and without dental amalgam fillings during the whole duration of the intervention study. Moreover, there was no statistically significant difference between the average age and $\mathrm{Hg}-\mathrm{B}$.

\section{Discussion}

In order to evaluate ingestion-related weekly mercury exposure in humans, we compared our results with the mentioned PTWI $(1.6 \mu \mathrm{g} / \mathrm{kg}$ bw/week) recommended by the JECFA [6]. This value was reflected in the individual food exposure. Moreover, the 50th and 95th percentile limits of estimates of average dietary exposure to $\mathrm{Hg}$ were also below the PTWI and amount of $0.62 \mu \mathrm{g} / \mathrm{kg}$ bw/week and $0.80 \mu \mathrm{g} / \mathrm{kg}$ bw/week, respectively. The risk index (percentage of the PTWI) amounts to $38.8 \%$ in the range $=22.7-59.8 \%$, and the hazard index (HI) of fish consumption (the ratio of EWI to PTWI) amounts to 0.39 . Despite the results, $32.8 \%$ of the volunteers exceeded the intake limit established by the US-NRC $(0.7 \mu \mathrm{g} /$ $\mathrm{kg}$ body weight). This intake was estimated taking into account a consumption of $800 \mathrm{~g} /$ week.

The tolerable daily intake (TDI) is an estimate of the average quantity of mercury from four selected fish, and it amounts to $10.5 \mu \mathrm{g} \mathrm{Hg}$. When this TDI value was divided by the average body weight, the estimated TDI was $0.12 \mu \mathrm{g} /$ $\mathrm{kg}$ of body weight - it was lower than the established by the JECFA value of $0.23 \mu \mathrm{g} / \mathrm{kg}$ of body weight [6]. The value is higher in the case of groups with high-fish consumption, e.g., TDI equals $16.3 \mu \mathrm{g} \mathrm{Hg}$ only for $M$. magellanicus 3 days per week, which corresponds with $0.19 \mu \mathrm{g} / \mathrm{kg}$ body weight. The average exposure to $\mathrm{MeHg}$ in our research project is unlikely to exceed the recommended value of PTWI; the likelihood of reaching such a PTWI level increases in the case of consumption of fish with higher $\mathrm{Hg}$ content. If people ate only $M$. magellanicus for 1 week (7 days), the EWI would be $1.34 \mu \mathrm{g} / \mathrm{kg}$ (84\% of PTWI in the range $=49.3-130 \%)$.

Differences in $\mathrm{Hg}$ levels in fish before and after heat treatment $(0.054 \pm 0.034 \mathrm{mg} / \mathrm{kg}$ vs. $0.058 \pm 0.033 \mathrm{mg} / \mathrm{kg}$. $)$ may be 
a result of dehydration process, and they depend on the species. Studies of other authors have suggested that differences concerning $\mathrm{Hg}$ in raw and fried fish may result from fish species [20,21], or even from Hg pre-concentration, formation of complexes involving $\mathrm{Hg}$ species, and sulfhydryl groups present in tissues [22]. Nevertheless, frying selected fish species in our research project did not reduce $\mathrm{Hg}$ content in fish considerably.

Wojciechowska-Mazurek et al. [23, 24] have shown results from the framework of monitoring research in Poland where the average mercury contamination in fish was $0.035 \mathrm{mg} / \mathrm{kg}$ and in seafood $0.022 \mathrm{mg} / \mathrm{kg}$ and at the 90 -percentile level, respectively, $0.062 \mathrm{mg} / \mathrm{kg}$ and $0.040 \mathrm{mg} / \mathrm{kg}$. Mercury intake from fish and fishery products for a person of $60 \mathrm{~kg}$ was estimated at 3.2 and $5.6 \%$ PTWI. Spodniewska et al. [25] have calculated percentage of PTWI taking into consideration the mean concentration of $\mathrm{Hg}$ in fish from lakes of Poland and the data from the Polish Central Statistical Office (2011). The results were $3.01 \%$ PTWI of $\mathrm{Hg}$ and $7.89 \%$ PTWI of MeHg.

According to the SCOOP (scientific cooperation on questions relating to food) report task, the estimated intakes of mercury in Europe varied depending on a country and on the amount and the type of fish consumed $[2,8,26]$. $\mathrm{MeHg}$ intake (assuming that all mercury is methylmercury and that $60 \mathrm{~kg}$ of body weight is considered for adults) was between $<0.1 \mu \mathrm{g} / \mathrm{kg}$ bw $/$ week for the Netherlands, through $0.3 \mu \mathrm{g} / \mathrm{kg}$ bw/week for France, and $1.6 \mu \mathrm{g} / \mathrm{kg}$ bw/week for Portugal. The range of high exposure to $\mathrm{THg}$ (the 95th or 97.5th percentile as high percentile of the distribution) was estimated depending on the country and amount and equaled $0.4 \mu \mathrm{g} / \mathrm{kg} \mathrm{bw} /$ week for Ireland, $1.8 \mu \mathrm{g} / \mathrm{kg} \mathrm{bw} / \mathrm{week}$ for Norway, and $2.2 \mu \mathrm{g} / \mathrm{kg}$ bw/week for Greece. The mean weekly consumption of fish and seafood products provided by the mentioned countries ranged from $70 \mathrm{~g}$ (the Netherlands), $245 \mathrm{~g}$ (France) to $350 \mathrm{~g}$ (Portugal); and for high intakes from $497 \mathrm{~g}$ (Greece), $525 \mathrm{~g}$ (Ireland) to $1925 \mathrm{~g}$ (Norway).

For adults ( $>14$ years, $n=1253$ ) in France, the mean consumption of fish and fishery food was $285 \mathrm{~g} /$ week, which results in mean exposure of $0.43 \mu \mathrm{g} \mathrm{MeHg} / \mathrm{kg}$ bw/week (median $=0.30 \mu \mathrm{g} / \mathrm{kg} \mathrm{bw} /$ week) and at the $97.5 \mathrm{th}$ percentile $=1.78 \mu \mathrm{g} / \mathrm{kg}$ bw $/$ week [27].

The THg intake of the Catalonian population was calculated based on the consumption data of 2158 people and amounted to $0.78 \mu \mathrm{g} / \mathrm{kg}$ bw/week. These results were compared with PTWI THg $(5 \mu \mathrm{g} / \mathrm{kg}$ of bw) [28]. Among 300 students of a middle secondary school in Sesimbra, Portugal [29] with the average number of fish meals consumed by each person 4.1 per week, the PTWI value applicable in Portugal $(1.6 \mu \mathrm{g} / \mathrm{kg} \mathrm{bw})$ reached the value of 4.5. For the median of the Italian fish and seafood consumers, the EWI for a person weighing $65 \mathrm{~kg}$ amounted to $0.88 \mu \mathrm{g} / \mathrm{week}$; it means $55 \%$ of PTWI $(1.6 \mu \mathrm{g} / \mathrm{kg}$ bw) [30].
Tang et al. [31] have estimated exposure to $\mathrm{THg}$ and $\mathrm{MeHg}$ in secondary school students in Hong Kong (data obtained by means of a semi-quantitative food frequency questionnaire) from fish intake at median levels: $\mathrm{THg}=0.5-0.6 \mu \mathrm{g} / \mathrm{kg} \mathrm{bw} /$ week (10-12\% PTWI, average consumer) and $1.6-1.9 \mu \mathrm{g} / \mathrm{kg}$ bw/week (32-38\% PTWI, high consumer) and $\mathrm{MeHg}=0.4-$ $0.5 \mu \mathrm{g} / \mathrm{kg}$ bw/week (25-31\% PTWI, average consumer) and 1.2-1.4 $\mu \mathrm{g} / \mathrm{kg}$ bw/week (75-88\% PTWI, high consumer). Authors compared their results with the PTWI value of THg equals $5 \mu \mathrm{g} / \mathrm{kg}$ bw/week set by the WHO in 1978 [1]. In another study from Hong Kong, Chen et al. [32] have shown that the average fish consumption (including seafood) for women in child-bearing age (20-49 years) amounted to $450 \mathrm{~g} /$ week. The high consumers ate $1500 \mathrm{~g}$ of fish and seafood per week. Their results indicate that the mean exposure to $\mathrm{MeHg}$ from the total diet was $0.68 \mu \mathrm{g} \mathrm{MeHg} / \mathrm{kg}$ bw/week (age 20-29 years), $0.78 \mu \mathrm{g} \mathrm{MeHg} / \mathrm{kg}$ bw/week (age 30-39 years), and $0.69 \mu \mathrm{g} \mathrm{MeHg} / \mathrm{kg}$ bw/week (age 40-49 years). The 95th percentile was $2.1,2.5$, and $2.4 \mu \mathrm{g} \mathrm{MeHg} / \mathrm{kg}$ bw/week, respectively. About $11 \%$ of those women had a dietary exposure to MeHg, exceeding the PTWI established by the JECFA.

For people from Japan, the world's top fish and seafood consumers, Yaginuma-Sakurai et al. [33] have conducted an intervention study. It took 14 weeks. Twenty-seven volunteers (14 men and 13 women) ate only two species of fish-large predators with expected high levels of mercury, i.e., bigeye tuna and swordfish. In Japan, the PTWI value, which is safe for adults, amounts to $3.4 \mu \mathrm{g} \mathrm{MeHg} / \mathrm{kg}$ bw/week. After the end of that, the observation continued for the next 15 weeks. During the experiment, the hair mercury levels were measured. Japanese people had baseline $\mathrm{THg}-\mathrm{H}$ level of $2.30 \pm 1.08$ (microgram per gram). Contrary to their volunteers, our study subjects had baseline $\mathrm{THg}-\mathrm{H}$ of $0.24 \pm 0.16 \mu \mathrm{g} / \mathrm{g}$. The authors compared our results with the PTWI value of THg $3.4 \mu \mathrm{g} / \mathrm{kg}$ bw/week recommended in 1973 by the Ministry of Health and Welfare of Japan.

Thapa et al. [34] have calculated MeHg intake (microgram per kilogram bw/week) based on fish consumption (kilogram per week) and $\mathrm{Hg}$ concentration in fish from Lake Phewa (Nepal) by different categories of people $(n=170)$. The minimum intake of $\mathrm{MeHg}(0.05 \mu \mathrm{g} / \mathrm{kg} \mathrm{bw} /$ week $)$ was found in the visitor (others) category, whereas hotel owners had the maximum intake $(3.71 \mu \mathrm{g} / \mathrm{kg}$ bw/week). The minimum fish consumption for visitors (others) was $0.1 \mathrm{~kg} /$ week, and the maximum fish consumption for hotel owners was $7.5 \mathrm{~kg} /$ week. Authors have confirmed that MeHg intake per kilogram body weight depended on the species of fish being consumed. A person can consume $6.3 \mathrm{~kg}$ of tilapia, $3.5 \mathrm{~kg}$ of African catfish, and $2 \mathrm{~kg}$ of spiny eel weekly, and still the PTWI established by the FAO/WHO $(1.6 \mu \mathrm{g} / \mathrm{kg}$ body weight $)$ will not be exceeded. However, the same person can consume only $2.7,1.5$, and $0.9 \mathrm{~kg}$ of the mentioned fish species weekly to not exceed intake limit of $0.7 \mu \mathrm{g} / \mathrm{kg}$ bw/week set by the US-NCR. 


\section{Conclusions}

The estimated weekly intake in our research did not exceed the PTWI value suggested by the JECFA/ESFA for MeHg $(1.6 \mu \mathrm{g} / \mathrm{kg}$ bw/week). However, $32.8 \%$ of the volunteers exceeded the PTWI values set by the US-NRC $(0.7 \mu \mathrm{g} / \mathrm{kg}$ body weight). Nevertheless, when we took into consideration one species of fish with the highest amount of mercury, i.e., $M$. magellanicus, the EWI value exceeded PTWI among 13\% individuals. Moreover, the results of average concentration of $\mathrm{Hg}$ in selected fish did not exceed the maximum permitted concentration (MPCs) for $\mathrm{Hg}$ in fish $-0.5 \mathrm{mg} / \mathrm{kg}$, established by the EU Commission Regulation (EC) [5]. The results indicate that the 67 volunteers of the research project would be unlikely to experience major toxicological effects of methylmercury.

Acknowledgement The authors thank Justyna Kazmierczak, Malgorzata Kaluza, and Wieslaw Kuszka for their excellence technical assistance.

\section{Compliance with Ethical Standards}

Conflict of Interest The authors declare that they have no conflict of interest.

Funding This study was funded by the Ministry of Science and Higher Education (Grant No. 2013/11/B/NZ7/04934).

Open Access This article is distributed under the terms of the Creative Commons Attribution 4.0 International License (http:// creativecommons.org/licenses/by/4.0/), which permits unrestricted use, distribution, and reproduction in any medium, provided you give appropriate credit to the original author(s) and the source, provide a link to the Creative Commons license, and indicate if changes were made.

\section{References}

1. WHO (1978) Mercury. In: safety evaluation of certain food additives and contaminants. Twenty-second meeting of the Joint FAO/ WHO Expert Committee on Food Additives (JECFA), Food Additives Series 13. WHO, Geneva Available on: http://www. inchem.org/documents/jecfa/jecmono/v13je14.htm

2. EFSA (European Food Safety Authority) (2015) Statement on the benefits of fish/seafood consumption compared to the risks of methylmercury in fish/seafood. European Food Safety Authority (EFSA). The EFSA J 13(1):3982 Available on: http://www.efsa. europa.eu/sites/default/files/scientific_output/files/main documents/3982.pdf

3. EFSA CONTAM Panel (EFSA Panel on Contaminants in the Food Chain) (2012) Scientific opinion on the risk for public health related to the presence of mercury and methylmercury in food. EFSA J 10(12):2985 Available on: http://www.efsa.europa. $\mathrm{eu} /$ sites/default/files/scientific_output/files/main_documents/2985. pdf
4. NRC (National Research Council) (2000) Committee on the toxicological effects of methylmercury. Toxicological effects of methylmercury. National Academy Press, Washington, DC

5. EC (European Commission) (2006) Commission Regulation No 1881/2006 of 19 December 2006 setting maximum levels for certain contaminants in foodstuffs (Text with EEA relevance). Available at: http://faolex.fao.org/docs/pdf/eur68134.pdf

6. JECFA (Joint FAO/WHO Expert Committee on Food Additives) (2003) Summary and conclusions of the sixty-first meeting of the Joint FAO/WHO Expert Committee on Food Additives (JECFA), pp. 18-22. Available on http://www.who.int/pcs/jecfa/Summary61. pdf

7. WHO (2004) Safety evaluation of certain food additives and contaminants WHO Food Additive Series No. 52. Methylmercury (Addendum). Available on: http://www.inchem. org/documents/jecfa/jecmono/v52je23.htm

8. EFSA (European Food Safety Authority) (2004) Opinion of the scientific panel on contaminants in the food chain on a request from the commission related to mercury and methylmercury in food. The EFSA J. 34, 1-14. Available on: http://www.efsa.europa. eu/sites/default/files/scientific output/files/main documents/34.pdf

9. Rojas M, Seijas D, Squiuante G, Pieters MĀ, Infante S (2007) Mercury in hair as a biomarker of exposure in a coastal Venezuelan population. Investig Clin 48(3):305-315

10. Brodzka R, Trzcinka-Ochocka M (2009) Merkury in hair-an indicator of environmental exposure. Polish. Med Pr 60(4):1-12 (in polish)

11. Farant JP, Brissette D, Moncion L, Bigras L, Chartrand A (1981) Improved cold-vapor atomic absorption technique for the microdetermination of total and inorganic mercury in biological samples. J Anal Toxicol 5:47-51

12. Harada M, Akagi H, Tsuda T, Kizaki T, Ohno H (1999) Methylmercury level in umbilical cords from patients with congenital Minamata disease. Sci Total Environ 234(30):59-62

13. Tahán JE, Granadillo VA, Sánchez JM, Cubillán HS, Romero RA (1993) Mineralization of biological materials prior to determination of total mercury by cold vapour atomic absorption spectrometry. J Anal At Spectrom 8:1005-1010

14. Afridi HI, Talpur FN, Kazi TG, Brabazon D (2015) Estimation of toxic elements in the samples of different cigarettes and their effect on the essential elemental status in the biological samples of Irish smoker rheumatoid arthritis consumers. Environ Monit Assess 187(4): 157

15. Maggi C, Berducci MT, Bianchi J, Giani M, Campanella L (2009) Methylmercury determination in marine sediment and organisms by direct mercury analyser. Anal Chim Acta 641(1-2):32-36

16. Torres DP, Martins-Teixeira MB, Silva EF, Queiroz HM (2012) Method development for the control determination of mercury in seafood by solid-sampling thermal decomposition amalgamation atomic absorption spectrometry (TDA AAS). Food Addit Contam Part A Chem Anal Control Expo Risk Assess 29(4):625-632

17. Ryabukhin YuS (1978) Activation analysis of hair as an indicator of contamination of man by environmental trace element pollutants. International Atomic Energy Agency, Vienna, Austria, IAEA/RL/ $50,1-134$

18. Shapiro SS, Wilk MB, Chen HJ (1968) A comparative study of various tests for normality. JASA 63:1343-1372

19. Royston JP (1982) An extension of Shapiro and Wilk's W test for normality to large samples. J R Stat Soc Series C Appl Stat 31(2): $115-124$

20. Ouédraogo O, Amyot M (2011) Effects of various cooking methods and food components on bioaccessibility of mercury from fish. Environ Research 8:1064-1069

21. Schmidt L, Bizzi CA, Duarte FA, Muller EI, Krupp E, Feldmann J, Flores EMM (2015) Evaluation of $\mathrm{Hg}$ species after culinary treatments of fish. Food Control 47:413-419 
22. Costa Fdo N, Korn MG, Brito GB, Ferlin S, Fostier AH (2016) Preliminary results of mercury levels in raw and cooked seafood and their public health impact. Food Chem 1:192-837-41

23. Wojciechowska-Mazurek M, Starska K, Brulińska-Ostrowska E, Plewa M, Karłowski K (2008) Monitoring studies of fish, seafood and their processed products related to the content of elements noxious to health. Polish. Bromat Chem Toksykol 41:525-529. 52

24. Wojciechowska-Mazurek M, Starska K, Mania M, BrulińskaOstrowska E, Biernat U, Karłowski K (2010) Monitoring of contamination of foodstuffs with elements noxious to human health, part II. Mineral, waters, soft drinks, fruits, nuts, rice, soybeans, fish and seafood. Polish. Rocz Panstw Zakl Hig 61:27-35

25. Spodniewska A, Barski D (2013) Concentration of some metals in the muscles of fish from selected lakes of Warmia and Mazury region (Poland). ACTA VET BRNO 82:067-071

26. SCOOP report 3.2.11 (2004) Assessment of the dietary exposure to arsenic, cadmium, lead and mercury of the population of the EU Member States. Brussels, Commission of the European Communities: Directorate-General of Health and Consumer Protection. Available at: http://ec.europa.eu/food/food/chemicalsafety/contaminants/scoop_3-211 heavy metals report en.pdf

27. Crépet A, Tressou J, Verger P, Leblanc JC (2005) Management options to reduce exposure to methyl mercury through the consumption of fish and fishery products by the French population. Regul Toxicol Pharmacol 42(2):179-189

28. Rodellar S, Fontcuberta M, Arqués JF, Calderon J, Ribas Barba L, Serra-Majem LL (2010) Mercury and methylmercury intake estimation due to seafood products for the Catalonian population (Spain). Food Addit Contam Part A 27(1):29-35

29. Carvalho CM, Matos AI, Mateus ML, Santos AP, Batoreu MC (2008) High-fish consumption and risk prevention: assessment of exposure to methylmercury in Portugal. J Toxicol Environ Health A 71(18):1279-1288

30. Pastorelli AA, Baldini M, Stacchini P, Baldini G, Morelli S, Sagratella E, Zaza S, Ciardullo S (2012) Human exposure to lead, cadmium and mercury through fish and seafood product consumption in Italy: a pilot evaluation. Food Addit Contam Part A Chem Anal Control Expo Risk Assess. 29(12):1913-1921

31. Tang AS, Kwong KP, Chung SW, Ho YY, Xiao Y (2009) Dietary exposure of Hong Kong secondary school students to total mercury and methylmercury from fish intake. Food Addit Contam Part B 2(1):8-14

32. Chen MY, Wong WW, Chung SW, Tran CH, Chan BT, Ho YY, Xiao Y (2014) Quantitative risk-benefit analysis of fish consumption for women of child-bearing age in Hong Kong. Food Addit Contam Part A 31(1):48-53

33. Yaginuma-Sakurai K, Murata K, Shimada M, Nakai K, Kurokawa N, Kameo S, Satoh H (2010) Intervention study on cardiac autonomic nervous effects of methylmercury from seafood. Neurotoxicol Teratol 32(2):240-245

34. Thapa DS, Sharma CM, Kang S, Sillanpää M (2014) The risk of mercury exposure to the people consuming fish from Lake Phewa, Nepal. Int J Environ Res Public Health 11(7):6771-6779 